\title{
ENERGY USE AND EFFICIENCY OF RICE-DRYING SYSTEMS I. ON-FARM CROSS-FLOW DRYER MEASUREMENTS
}

\author{
M. A. Billiris, T. J. Siebenmorgen, G. L. Baltz
}

\begin{abstract}
Energy use and efficiency of an on-farm, cross-flow dryer were measured by performing five tests during the harvest season of 2011 and three tests during the harvest season of 2012. Thermal energy requirements were expressed in terms of energy per unit mass water removed, by dividing the energy requirements of the burner by the total mass of water removed for each drying run. Energy efficiency was calculated as the ratio of theoretical energy requirements to the measured energy requirements. In 2011, energy requirements to dry rice ranged from 2,840 to 5,310 kJ/kg water removed, with harvest moisture contents ranging from $16.6 \%$ to $21.7 \%$, and in 2012 from 3,730 to $5,840 \mathrm{~kJ} / \mathrm{kg}$ water removed, with harvest moisture contents ranging from 17.4\% to 18.2\%. Thermal energy efficiencies ranged from $47 \%$ to $90 \%$ in 2011 and from $44 \%$ to $69 \%$ in 2012. The difference between drying air temperature inside the dryer and ambient air temperature as well as the amount of water removed, expressed on a per unit mass of rice dry matter, significantly impacted energy use. Equations were developed to predict energy use and efficiency as a function of these two parameters.
\end{abstract}

Keywords. On-farm dryer, Rice drying, Thermal energy efficiency, Thermal energy requirements.

W hen rice is harvested at high moisture content (MC) it is typically dried quickly to preserve its quality (Siebenmorgen and Meullenet, 2004). Unless some form of cooling is provided, harvested rice should be dried to a safe $\mathrm{MC}$ of $13 \%$ to allow long-term storage (All moisture contents are reported on a wet basis unless otherwise specified. Howell and Cogburn, 2004). Rice production has increased 3.5 fold from the year 1960 to 2012 (USDA, 2013), the amount of rice that needs to be dried has increased significantly. In addition, global rice production is expected to continue increasing due to predicted growth trends in world population.

Verma (1994) reported that the energy equivalent of 630 million gal of crude oil was used to dry grains in the United States in 1994. Kasmaprapruet et al. (2009) reported that drying was the unit operation that required the most energy for rice processing, accounting for $55 \%$ of the total energy consumed for production and processing of rice. Drying was followed by harvesting $(15 \%)$, cultivation $(10 \%)$, seeding $(10 \%)$, transportation $(6 \%)$, and milling $(4 \%)$.

Arkansas is the leading rice producing state in the United States with $47 \%$ of the rice-planted acres (USDA, 2011) and is the state in which this study was conducted. While most of the rice produced in Arkansas is dried in

Submitted for review in June 2013 as manuscript number FPE 10286; approved for publication by the Food \& Process Engineering Institute of ASABE in November 2013.

The authors are Maria Alejandra Billiris, ASABE Member, Graduate Student, Terry J. Siebenmorgen, ASABE Fellow, University Professor, Department of Food Science, University of Arkansas, Fayetteville, Arkansas; and Gregory L. Baltz, Rice Producer, Running Lake Farms, Pocahontas, Arkansas. Corresponding author: Terry J. Siebenmorgen, 2650 N. Young Ave, Fayetteville, AR 72704; phone: 479575-2841; e-mail: tsiebenm@uark.edu. commercial, cross-flow driers, a significant portion is dried on farms and is usually dried in bins at low temperatures (Ts) ranging from $25^{\circ} \mathrm{C}$ to $38^{\circ} \mathrm{C}$ and airflow rates ranging from 0.03 to $0.10 \mathrm{~m}^{3} / \mathrm{s} / \mathrm{m}^{3}$ of grain $(2.2$ to $7.5 \mathrm{cfm} / \mathrm{bu}$ ) (Bakker-Arkema and Fontana, 1983). However, because rice production has increased in the past decades, there has been a shift in on-farm drying to portable, cross-flow dryers, similar to the one used in this study, thus relieving pressure on commercial dryers; this trend has also been noted in the corn industry (Morey et al., 1976).

The Economic Research Service (2004) reported that for the rice farms in Arkansas in which rice is dried, drying accounts for $\sim 38 \%$ of the cost of on-farm production and processing operations, including drying, fertilizers, chemical application, and harvest. Drying cost varied significantly on U.S. rice farms in 2000, ranging from $22 \$ /$ ha (9 \$/acre) to $72 \$ /$ ha ( 29 \$/acre) depending on the rice production region (Economic Research Service, 2004). Because of the relative importance of drying to overall energy use for rice production/processing, and that there is little information on energy requirements of rice drying, it is relevant to measure the amount of energy that is currently required to dry rice and to determine the energy efficiency of rice drying systems in order to maximize the drying achieved per unit energy used.

In order to assess the energy performance of a drying process, the specific heat consumption, calculated by dividing the total energy supplied to the dryer by the mass of water evaporated from the grain (Mujumdar, 1995), may be used to represent the actual energy requirements of a dryer on a per unit mass of water removed. Brinker and Anderley (2012) reported average specific heat consumptions of $4,810 \mathrm{~kJ} / \mathrm{kg}$ water removed for an on-farm, crossflow dryer with heat recovery when drying 3,100 metric tonnes $(122,076 \mathrm{bu})$ of corn using an average air $\mathrm{T}$ of $4.5^{\circ} \mathrm{C}$ 
$\left(40^{\circ} \mathrm{F}\right)$ and of $4,203 \mathrm{~kJ} / \mathrm{kg}$ water removed for another onfarm, cross-flow dryer when drying 31,116 metric tonnes $(1,225,000 \mathrm{bu})$ of grain from $22 \%$ to $15 \%$ MC using an average ambient $\mathrm{T}$ of $3.3^{\circ} \mathrm{C}\left(38^{\circ} \mathrm{F}\right)$. The same study reported that an on-farm, cross-flow horizontal dryer without heat recovery used $6,530 \mathrm{~kJ} / \mathrm{kg}$ water removed to dry grain.

To determine energy efficiency, the theoretical energy required $\left(\mathrm{E}_{\text {theo }}\right)$ for moisture removal (Kudra, 2004), which represents the minimum energy required to dry grain, is typically compared to the specific heat consumption. The minimum energy required to dry grains is predominantly the energy required to evaporate water, which varies from 2,500 to $2,670 \mathrm{~kJ} / \mathrm{kg}$ water depending on the drying $\mathrm{T}$ (Fluck and Baird, 1980). Billiris et al. (2011) reported that Etheo to dry long-grain rice to $12.5 \%$ ranged from 2,500 to $2,650 \mathrm{~kJ} / \mathrm{kg}$ water when the initial $\mathrm{MC}\left(\mathrm{MC}_{\mathrm{i}}\right)$ ranged from $22 \%$ to $15 \%$, respectively, at a $40{ }^{\circ} \mathrm{C}$ kernel $\mathrm{T}$.

The objectives of this research were to measure the energy use and efficiency of an on-farm, cross-flow dryer operating across a range of ambient and drying air conditions.

\section{Materials ANd Methods \\ DRYER AND DRYING SYSTEM DESCRIPTION}

Figure 1A shows a side-view of the dryer (Portable grain dryer 1126, GSI Group, LLC, Assumption, Ill.), which had a holding capacity of $1,100 \mathrm{bu}(22,420 \mathrm{~kg})$, used in this
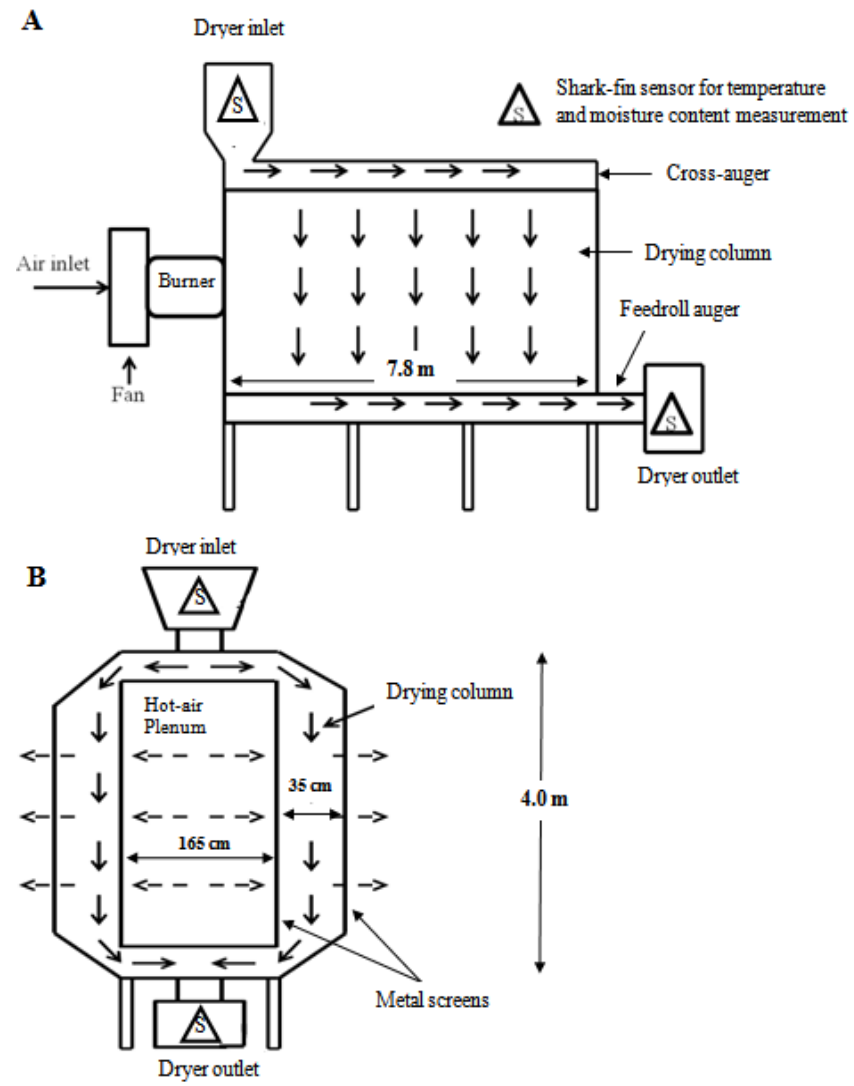

Figure 1. (a) Side view of the on-farm, cross-flow dryer. (b) Vertical cross-section of the dryer. study and located at Pocahontas, Arkansas. Figure 1B shows a vertical cross-section of the dryer. After entering the dryer inlet, rice is transferred to the drying columns by a cross-auger where it flows by gravity through the columns (fig. 1A). Two variable-speed, feedroll augers located at the bottom of the dryer transport the dried rice to the outlet and controls the flow rate of the rice inside the columns based on a target output MC. Ambient air is forced through the dryer by an axial-flow fan (40 hp 42 in., GSI Group, LLC, Assumption, Ill.). Immediately after exiting the fan, the air is heated by a burner $(10.25 \mathrm{mil} \mathrm{Btu} / \mathrm{h}$ max, GSI Group, LLC, Assumption, Ill.) by direct combustion of propane gas before entering the dryer hot-air plenum (HAP) (fig. 1A). From the HAP, the drying air passes through the rice columns perpendicular to the downward flow of the rice (fig. 1B). Screens are located on both sides of each drying column, allowing the drying air to enter and exit the columns (fig. 1B).

The drying system utilized in this study encompasses the dryer described above, two hopper-bottom bins, final storage bins, and a 10 in. closed-'loop' paddle chain conveying system. In this drying system, rice is typically pre-heated, dried in two passes, tempered after each pass, and aerated in a storage bin (fig. 2). More specifically, freshly harvested rice is pre-heated to $\sim 30^{\circ} \mathrm{C}\left(85^{\circ} \mathrm{F}\right)$ in a $497 \mathrm{~m}^{3}$ (14,961 bu) hopper-bottom bin (FCHT 45 $-24 \mathrm{ft}$ diameter, 9 ring, GSI Group, LLC, Assumption, Ill.) with a $16.18 \mathrm{~m}$ peak height. Pre-heating is accomplished by forcing ambient air through the rice bin using a centrifugal fan (CHS-10 hp $3450 \mathrm{rpm}$, GSI Group, LLC, Assumption, Ill.) and heating the air with an upstream burner (VHD-18VN, .4 to $1.4 \mathrm{mil} \mathrm{Btu/h}$, GSI Group, LLC, Assumption, Ill.). After pre-heating, rice is conveyed to the inlet of the dryer. During the first drying pass, which is carried out using a target drying air $\mathrm{T}$ of $57^{\circ} \mathrm{C}\left(135^{\circ} \mathrm{F}\right)$, rice is dried from the MCi of typically $18 \%$ to $21 \%$ to $\sim 15.5 \%$. After the first drying pass, rice is tempered in the second hopperbottom bin, identical to the first, for a duration of $\sim 1$ to $10 \mathrm{~h}$. During the second pass, which is carried out using a target drying air $\mathrm{T}$ of $49^{\circ} \mathrm{C}\left(120^{\circ} \mathrm{F}\right)$, rice is usually dried from $\sim 15.5$ to $\sim 12.5 \% \mathrm{MC}$, and is then conveyed from the dryer outlet to a 4,200 $\mathrm{m}^{3}$ storage bin (FCDL $60 \mathrm{ft}$ diameter 13 ring, GSI Group, LLC, Assumption, Ill.) with a $18.3 \mathrm{~m}$ diameter and $19.7 \mathrm{~m}$ peak height where it is first tempered for $2 \mathrm{~h}$ and then aerated using ambient air at a rate of $1,643 \mathrm{~m}^{3} / \mathrm{min}(58,000 \mathrm{cfm})$ for an apparent velocity of $6.3 \mathrm{~m}^{3} / \mathrm{min} / \mathrm{m}^{2}$ using two centrifugal fans (CF-40, GSI Group, LLC, Assumption, Ill.).

\section{ENERGY TESTS}

Energy consumption was measured during the 2011 and 2012 rice harvest seasons. Five drying tests were conducted during the first year and three tests were conducted during

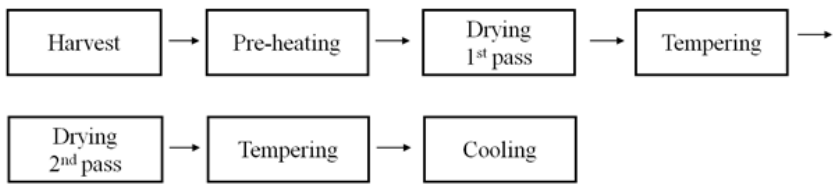

Figure 2. Flow diagram of the drying system operation. 
Table 1. Synopsis of drying-energy tests performed using an on-farm, cross-flow drier in 2011 and 2012.

\begin{tabular}{|c|c|c|c|c|c|c|}
\hline \multirow[b]{2}{*}{ Test } & \multirow[b]{2}{*}{$\begin{array}{l}\text { Number } \\
\text { of Passes }\end{array}$} & \multirow{2}{*}{$\begin{array}{c}\text { Mass of Rice } \\
\text { at } \mathrm{MC}_{\mathrm{i}} \\
(\mathrm{kg})\end{array}$} & \multirow{2}{*}{$\begin{array}{c}\mathrm{MC}_{\mathrm{i}}^{[\mathrm{a}]} \\
\text { (first pass) } \\
\text { (\%w.b.) }\end{array}$} & \multirow{2}{*}{$\begin{array}{c}\mathrm{MC}_{\mathrm{f}}^{[\mathrm{b}]} \\
\text { (final pass) } \\
\text { (\% w.b.) }\end{array}$} & \multicolumn{2}{|c|}{ Drying Pass Temperatures $\left(\mathrm{T}_{\mathrm{da}} / \mathrm{T}_{\mathrm{a}}\right)^{[\mathrm{c}}$} \\
\hline & & & & & $\begin{array}{l}\text { First } \\
\left({ }^{\circ} \mathrm{C}\right) \\
\end{array}$ & $\begin{array}{c}\text { Second } \\
\left({ }^{\circ} \mathrm{C}\right)\end{array}$ \\
\hline & & \multicolumn{5}{|c|}{ Drying Season: September - October 2011} \\
\hline 1 & 2 & 271,410 & 21.7 & 13.0 & $56 / 23$ & $49 / 16$ \\
\hline 2 & 1 & 185,710 & 18.6 & 13.3 & $49 / 18$ & $\ldots$ \\
\hline 3 & 1 & 214,280 & 16.6 & 13.2 & $48 / 29$ & $\ldots$ \\
\hline 4 & 2 & 295,910 & 18.9 & 13.3 & $50 / 27$ & $46 / 14$ \\
\hline 5 & 2 & 240,810 & 21.0 & 13.3 & $45 / 20$ & $48 / 17$ \\
\hline & & \multicolumn{5}{|c|}{ Drying Season: August - October 2012} \\
\hline 1 & 2 & 221,930 & 17.6 & 12.6 & $52 / 19$ & $43 / 22$ \\
\hline 2 & 2 & 222,910 & 18.2 & 12.7 & $49 / 9.0$ & $44 / 23$ \\
\hline 3 & 1 & 332,930 & 17.4 & 12.4 & $44 / 22$ & $\ldots$ \\
\hline
\end{tabular}

a] $\mathrm{MC}_{\mathrm{i}}$ is the harvest moisture content.

[b] $\mathrm{MC}_{\mathrm{f}}$ is the moisture content after the final pass.

[c] $\mathrm{T}_{\mathrm{da}}$ is the average temperature of the drying air inside the hot-air plenum during each run; $\mathrm{T}_{\mathrm{a}}$ is the average ambient temperature during each run.

the second year (table 1). In 2011, three tests were performed following the typical two-pass drying procedure described above and two tests were performed in which rice was dried in a single pass directly from MCi to $\sim 12.5 \%$ using drying air Ts of $\sim 50^{\circ} \mathrm{C}\left(122^{\circ} \mathrm{F}\right)$. All tests comprised drying long-grain, "CL XL745" rough rice, which is reported to have kernel dimensions of: length $=9.61 \mathrm{~mm}$, width $=2.71 \mathrm{~mm}$, and thickness $=1.97 \mathrm{~mm}$ (RiceTec Grain Quality Profiler, 2013), for durations ranging from 10 to $20 \mathrm{~h}$, depending on the number of passes, $\mathrm{MC}_{\mathrm{i}}$, and ambient conditions. For the terminology of this article, a "run" is a single pass of a given lot of rice through the dryer, a drying test typically comprised two runs.

\section{Energy Measurement and Calculation}

The thermal energy requirements $\left(\mathrm{E}_{\text {thermal }}\right)$ to dry rice in terms of energy per unit mass water removed, referred to above as the specific energy consumption, were calculated using equation 1 (Maier and Bakker-Arkema, 2002):

$$
\mathrm{E}_{\text {thermal }}=\frac{\mathrm{V} \times \mathrm{AE}}{\mathrm{m}_{\mathrm{w}}}
$$

$\mathrm{E}_{\text {thermal }}=$ the thermal energy supplied to the dryer in $\mathrm{kJ} / \mathrm{kg}$ water removed,

$\mathrm{V}=$ the volume of propane gas used $\left(\mathrm{m}^{3}\right)$,

$\mathrm{AE}=$ the available energy from propane $\sim 93,743 \mathrm{~kJ} / \mathrm{m}^{3}$ $\left(2,516 \mathrm{Btu} / \mathrm{ft}^{3}\right)$, which was used to compute $\mathrm{E}_{\text {thermal }}$, was obtained from the propane supplier. The high heating value of propane equal to $94,787 \mathrm{~kJ} / \mathrm{m}^{3}\left(2,544 \mathrm{Btu} / \mathrm{ft}^{3}\right)$, which was obtained after multiplying the high heating value reported by Neil (2003) $50,365 \mathrm{~kJ} / \mathrm{kg}(21,653 \mathrm{Btu} / \mathrm{lb})$ by the density of propane gas at $15^{\circ} \mathrm{C}$ and $101.3 \mathrm{kPa}$ $\left(1.88 \mathrm{~kg} / \mathrm{m}^{3}\right)$, was used as a comparative value.

$\mathrm{m}_{\mathrm{w}} \quad=$ the mass of water removed during each drying run $(\mathrm{kg})$.

Note: Thermal energy use for an entire test was calculated by summing the volumes of propane used $(\mathrm{V})$ and the masses of water removed (mw) for all runs comprising a test.

The volume of propane gas used by the burners (dryer and pre-heating bin) was measured using two, diaphragmflow meters (AL-425, Elster American Meter, Nebraska City, Nebr.) that had an accuracy of \pm 1 to $2 \%$ of the reading. The flow meters had a maximum operating pressure of $172 \mathrm{kPa}(25 \mathrm{psi})$ and T-compensating capabilities for ambient Ts ranging from $-34^{\circ} \mathrm{C}$ to $60^{\circ} \mathrm{C}$ $\left(-29^{\circ} \mathrm{C}\right.$ to $\left.140^{\circ} \mathrm{F}\right)$. Liquid propane was stored in a $21 \mathrm{~m}^{3}$ tank that was equipped with a calibrated gauge (2582C Rotoguage, Bastian Blessing Co., Chicago, Ill.), which measured the percentage of the tank volume that was occupied by liquid propane. The propane consumption determined using this gauge was used to calibrate the flow meters at the dryer. To obtain the volume of liquid propane used for a given run, percent liquid volume readings were recorded before and after each drying run. The volume of liquid propane used was converted to volume of propane gas; the latter volume was used to calibrate the flow meters. After multiple trials, a calibration factor of 1.45 was obtained. This calibration factor was applied to all flow meter readings to obtain the volume of propane used during the energy runs.

The mass of water removed during each run was calculated using equation 2 (Maier and Bakker-Arkema, 2002).

$$
\mathrm{m}_{\mathrm{w}}=\frac{\mathrm{m}_{\mathrm{r}} \times\left(\mathrm{MC}_{\mathrm{i}}-\mathrm{MC}_{\mathrm{f}}\right)}{100-\mathrm{MC}_{\mathrm{f}}}
$$

$\mathrm{m}_{\mathrm{r}} \quad=$ the mass of incoming rice dried in a drying run $(\mathrm{kg})$

$\mathrm{MC}_{\mathrm{i}}=$ the average moisture content of the rice entering a drying run (\%, w.b.)

$\mathrm{MC}_{\mathrm{f}}=$ the average moisture content of the rice exiting a drying run (\%, w.b.)

The mass of incoming rice lots ranged from 109,260 to $271,000 \mathrm{~kg}$ for the drying tests of 2011, and from 213,580 to $333,000 \mathrm{~kg}$ in 2012 . Each rice lot comprised rice from the same field that was harvested and transported using trucks that held approximately $23,000 \mathrm{~kg}$; a typical test run comprised a day's harvest of 9 to 13 trucks. The mass of incoming rice comprising a rice lot was calculated as the sum of the masses of incoming rice on each truck. To obtain the mass of incoming rice on each truck, the mass of the truck loaded with freshly-harvested rice was measured on a local elevator scale, and then the mass of the empty truck was subtracted. The mass of incoming rice in subsequent loads was obtained by subtracting the mass of the empty truck previously obtained from the mass of the truck loaded with rice. 
The harvest MC (before pre-heating) of each rice lot was obtained from the combine harvester (CR 9070, New Holland, Pa.), which was equipped with a sensor that provides the average $\mathrm{MC}$ of the rice comprising a lot. The $\mathrm{MC}$ of the rice entering (after pre-heating) and exiting the dryer throughout a given drying run was measured using shark-fin sensors (GSI Group, LLC, Assumption, Ill.) that were located at the inlet and outlet of the dryer (fig. 1A) and that were calibrated weekly using a calibrated moisture meter (GAC 2100, DICKEY-John, Auburn, Ill.) that had an accuracy of $0.15 \%$. The shark-fin sensors were programmed to record $\mathrm{T}$ and $\mathrm{MC}$ of the rice every $3 \mathrm{~min}$. For any given drying run, the $\mathrm{MC}$ of the rice entering and exiting the dryer was calculated as the average of the MCs recorded by the inlet and outlet shark-fin sensors during the run. Because pre-heating could have reduced MC, the harvest MC determined by the combine sensor was deemed appropriate to represent the $\mathrm{MC}_{\mathrm{i}}$ of the rice throughout the first drying pass. In addition, it was reasoned that there might be an offset in the reading of the outlet shark-fin sensor, which measures predominantly surface moisture, due to the formation of a moisture gradient inside the rice kernels during drying and thus the MC at the surface would be less than that at the core (Sarker et al., 1996;Yang et al., 2003). Therefore, the MC measured by the inlet shark-fin sensor during the second pass, which represents the $\mathrm{MC}$ of the rice after first-pass tempering, was considered to be a better indicator of the rice $\mathrm{MC}$ exiting the dryer $\left(\mathrm{MC}_{\mathrm{f}}\right)$ of the first pass. Thus, if drying was performed in two passes, to calculate the mass of water removed during the first pass via equation 2, the average harvest $\mathrm{MC}$ from the combine was used as the $\mathrm{MC}_{\mathrm{i}}$ and the average inlet shark-fin sensor MC obtained for the second pass was used as the first-pass $\mathrm{MC}_{\mathrm{f}}$.

To obtain an appropriate $\mathrm{MC}_{\mathrm{f}}$ for the second pass, the $\mathrm{MC}$ of tempered rice was measured on two samples from each run, which were taken from the storage bins after tempering, using the moisture meter described previously. This ensured that $\mathrm{MC}$ gradients inside rice kernels had subsided and thus the $\mathrm{MC}$ measured was the actual $\mathrm{MC}_{\mathrm{f}}$ of the rice. Thus, to calculate the mass of water removed during the second pass via equation 2 , the average inlet shark-fin sensor MC obtained for the second pass was used as the $\mathrm{MC}_{\mathrm{i}}$ and the tempered rice $\mathrm{MC}$ was used as the $\mathrm{MC}_{\mathrm{f}}$. If drying was performed in a single pass, the harvest $\mathrm{MC}$ was used as the $\mathrm{MC}_{\mathrm{i}}$ of the rice and the tempered rice $\mathrm{MC}$ was used as the $\mathrm{MC}_{\mathrm{f}}$.

Electrical energy requirements to power fans and augers were not measured due to limitations in isolating energy requirements for this equipment. This was not deemed a major study limitation since Hellevang and Reff (1987) reported that propane use is responsible for $98 \%$ of the energy requirements when drying grain using hightemperatures. To corroborate the findings reported by Hellevang and Reff (1987), electrical energy requirements $\left(E_{\text {elec }}\right)$ were estimated using nameplate information $(40 \mathrm{hp})$ of the fan and the fan operation durations.

\section{Energy Efficiency Calculation}

The energy efficiency of the dryer for a given drying run was calculated using equation 3 .

$$
\eta=\frac{E_{\text {theo }}}{E_{\text {thermal }}} \times 100
$$

$\eta \quad=$ the energy efficiency of the drying process,

$\mathrm{E}_{\text {theo }}=$ the theoretical energy in $\mathrm{kJ} / \mathrm{kg}$ water removed,

$\mathrm{E}_{\text {thermal }}=$ the thermal energy supplied to the dryer (specific heat consumption) in $\mathrm{kJ} / \mathrm{kg}$ water removed.

The theoretical energy requirement $\left(\mathrm{E}_{\text {theo }}\right)$ represents the amount of energy required to dry rice from a given $\mathrm{MC}_{\mathrm{i}}$ to a $\mathrm{MC}_{\mathrm{f}}$ at a given kernel $\mathrm{T}$ under ideal conditions. To predict $E_{\text {theo, }}$, the equation developed by Billiris et al. (2011) for long-grain, non-parboiled rice was used (eq. 4).

$$
\begin{aligned}
\mathrm{E}_{\text {theo }} & =(3,189,745-2,496 \mathrm{~T})\left(\mathrm{MC}_{\mathrm{i}}-\mathrm{MC}_{\mathrm{f}}\right) \\
& +\left(e^{-24.2 \mathrm{MC}_{\mathrm{i}}}-e^{-24.2 \mathrm{MC}_{\mathrm{f}}}\right)\left(\frac{9,742,417}{-24.2}\right)
\end{aligned}
$$

$\mathrm{E}_{\text {theo }}=$ the theoretical energy requirement $(\mathrm{J} / \mathrm{kg}$ dry matter),

$\mathrm{MC}_{\mathrm{i}}=$ initial moisture content in dry basis (decimal)

$\mathrm{MC}_{\mathrm{f}}=$ the final moisture content in dry basis (decimal),

$\mathrm{T}=$ the kernel temperature $\left({ }^{\circ} \mathrm{K}\right)$.

To express energy requirements on a per unit mass of water removed, equation 4 was divided by the mass of water removed during a drying run (mw; eq. 2) per mass of rice dry matter associated with a drying run.

\section{TEMPERATURE AND RELATIVE HUMIDITY \\ MEASUREMENTS}

The $\mathrm{T}$ and $\mathrm{RH}$ of the ambient air and that inside the HAP were measured continuously throughout all drying trials using T and RH sensors (Hobo Pro v2 U23-001, Onset Corporation, Bourne, Mass.). Sensors had datalogging capability and were programmed to record $\mathrm{T}$ and RH measurements every $5 \mathrm{~min}$. Ambient conditions were measured using a sensor that was located at the fan inlet. It is noted that the HAP T was obtained as the average $\mathrm{T}$ from four sensors located throughout the HAP.

All statistical analyses were performed using software (JMP Pro 9, SAS Institute, Inc., Cary, N.C.) and the p-value was set at 0.05 .

\section{RESULTS AND DISCUSSION \\ Moisture Content Measurements}

Figure 3A shows harvest and inlet MCs, which represent rice MCs before and after pre-heating, respectively, for the 2011 drying tests. It is noted that the inlet MC refers to the $\mathrm{MC}$ of the rice at the inlet of the dryer (fig. 1) as measured by the inlet shark-fin sensor. In general, harvest MCs were greater than inlet MCs. It is reasoned that rice was partially dried during the pre-heating step and thus the slight reduction in MC. This trend was more apparent as rice inlet $\mathrm{MC}$ increased, speculated to be due to the increasing ease of water removal from rice with greater MCs. It is possible that the pre-heating step improves the energy efficiency of the drying process, not only because rice is heated to the drying $\mathrm{T}$ in the pre-heating bin, but also because some moisture is removed during pre-heating. 

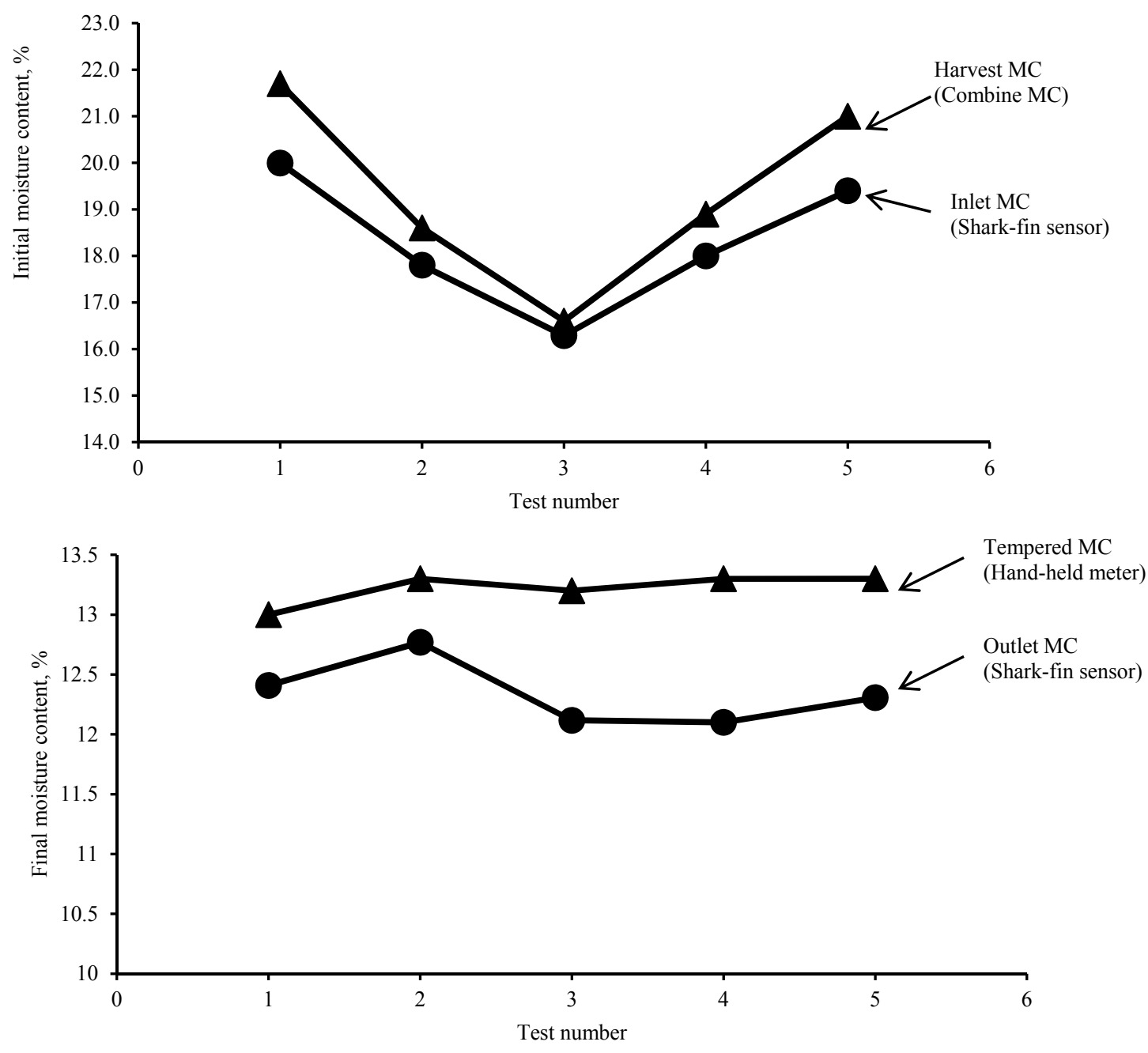

Figure 3. Initial (A) and final (B) moisture contents (MCs) of the rice lots for the five drying tests carried out in 2011 (table 1). Harvest MC refers to the average MC of each rice lot measured by the moisture sensor in the combine. Inlet and outlet MCs represent the average MCs measured by the shark-fin sensors at the inlet and outlet of the dryer throughout a drying run, respectively. When tests were conducted in two passes, the inlet MC corresponds to the inlet MC during the first pass and the outlet MC corresponds to the outlet MC of the second pass. Tempered MCs represent the MCs measured using a hand-held meter after the rice had tempered in a storage bin. Data points indicate the mean of two MC measurements of two samples from the same lot.

Figure 3B shows tempered and outlet MCs for the 2011 drying tests. The outlet $\mathrm{MC}$ refers to the $\mathrm{MC}$ of the rice at the outlet of the dryer (fig. 1) as measured by the outlet shark-fin sensor. It is noted that the outlet MCs shown in figure $3 \mathrm{~B}$ correspond to the outlet $\mathrm{MC}$ of the second pass when tests were carried out in two passes. Tempered rice MCs, which were $\sim 13 \%$, were always greater than the outlet MCs measured by the outlet shark-fin sensor. This can be explained by Sarker et al. (1996) and Yang et al. (2003) who stated that during drying a moisture gradient develops inside the rice kernel in which the moisture at the core is greater than that at the surface of the kernel. However, during tempering the moisture at the core migrates to the surface of the kernel, producing a more uniform kernel MC. Because shark-fin and hand-held meters measure predominantly the surface $\mathrm{MC}$, the $\mathrm{MC}$ value obtained at the dryer outlet was less than that obtained after tempering (fig. 3B). This justifies using tempered rice $\mathrm{MC}$ as a more appropriate $\mathrm{MC}$ measurement of rice exiting the dryer for energy calculations.

\section{ENERGY REQUIREMENTS AND EFFICIENCY}

Table 2 shows $\mathrm{E}_{\text {theo }}, \mathrm{E}_{\text {thermal }}, \mathrm{E}_{\text {elec }}$, and thermal energy efficiency for the drying tests conducted in 2011 and 2012. $\mathrm{E}_{\text {thermal }}$ varied from 2,840 to $5,310 \mathrm{~kJ} / \mathrm{kg}$ water in 2011 ; whereas the predicted $\mathrm{E}_{\text {theo }}$ ranged from 2,480 to 2,560 $\mathrm{kJ} / \mathrm{kg}$ water removed. In addition, $\mathrm{E}_{\text {thermal }}$ varied from 3,730 to $5,840 \mathrm{~kJ} / \mathrm{kg}$ water in 2012 ; whereas the predicted $\mathrm{E}_{\text {theo }}$ ranged from 2,550 to $2,570 \mathrm{~kJ} / \mathrm{kg}$ water removed. Thus, energy requirements obtained for the second year of testing were consistent to those of the first year. In general, the $\mathrm{E}_{\text {thermal }}$ values reported in table 2 are within the values reported by Maier and Bakker-Arkema (2002), which ranged from 3,480 to $10,450 \mathrm{~kJ} / \mathrm{kg}$ water removed. In addition, Otten et al. (1980), who performed drying tests to determine the energy required to dry corn in a commercial cross-flow dryer, reported that $\mathrm{E}_{\text {thermal }}$ varied from 3,860 to $11,960 \mathrm{~kJ} / \mathrm{kg}$ water removed. Electrical energy requirements, which were estimated based on nameplate information, accounted for approximately $3 \%$ of the total 
Table 2. Energy requirements and energy efficiency for the tests conducted in 2011 and 2012.

\begin{tabular}{|c|c|c|c|c|c|}
\hline Test & $\begin{array}{c}\text { Propane } \\
\text { Consumed }^{[\mathrm{a}]} \\
\left(\mathrm{m}^{3}\right)\end{array}$ & $\begin{array}{c}E_{\text {theo }}{ }^{[\mathrm{b}]} \\
(\mathrm{kJ} / \mathrm{kg})\end{array}$ & $\begin{array}{c}E_{\text {thermal }}{ }^{[\mathrm{c}]} \\
(\mathrm{kJ} / \mathrm{kg})\end{array}$ & $\begin{array}{c}E_{\text {elec }}{ }^{[\mathrm{d}]} \\
(\mathrm{kJ} / \mathrm{kg})\end{array}$ & Efficiency $^{[\mathrm{e}]}$ \\
\hline & \multicolumn{5}{|c|}{ Drying Season: September - October 2011} \\
\hline 1 & 1410 & 2,480 & 4,870 & 160 & 51 \\
\hline 2 & 526 & 2,540 & 4,340 & 140 & 58 \\
\hline 3 & 255 & 2,560 & 2,840 & 140 & 90 \\
\hline 4 & 866 & 2,520 & 4,250 & 145 & 59 \\
\hline 5 & 1211 & 2,510 & 5,310 & 140 & 47 \\
\hline & \multicolumn{5}{|c|}{ Drying Season: July-October 2012} \\
\hline 1 & 791 & 2,560 & 5,840 & 170 & 44 \\
\hline 2 & 760 & 2,550 & 5,070 & 104 & 50 \\
\hline 3 & 757 & 2,570 & 3,730 & 100 & 69 \\
\hline
\end{tabular}

[a] Values represent gaseous volumes

[b] $E_{\text {theo }}$ is the theoretical energy requirement in $\mathrm{kJ} / \mathrm{kg}$ water removed.

[c] $E_{\text {thermal }}$ is the measured thermal energy requirement in $\mathrm{kJ} / \mathrm{kg}$ water removed.

[d] $\mathrm{E}_{\text {elec }}$ is the electrical energy requirements to operate the fan, which was estimated using nameplate information (40 hp) and fan operation duration.

[e] Energy efficiency was calculated as the ratio of $E_{\text {theo }}$ divided by $\mathrm{E}_{\text {thermal. }}$.

energy requirements $\left(\mathrm{E}_{\text {thermal }}+\mathrm{E}_{\text {elec }}\right)$, similar to the values reported by Hellevang and Reff (1987).

Energy efficiencies were calculated using equation 3 for each test and ranged from $47 \%$ to $90 \%$ in 2011 and from $44 \%$ to $69 \%$ in 2012 (table 2). Otten et al. (1980) reported thermal energy efficiencies to dry corn in a cross-flow dryer of $24 \%$ to $76 \%$, which were calculated by dividing the heat of vaporization of corn at $40^{\circ} \mathrm{C}$ and $15 \% \mathrm{MC}$ dry basis by the specific heat consumption. The following sections discuss the effects of various factors on $\mathrm{E}_{\text {thermal }}$ and energy efficiency.

\section{EFFECT OF DRYING AIR TEMPERATURE AND AMBIENT TEMPERTURE ON ENERGY USE AND EFFICIENCY}

The different passes through the dryer were carried out under considerably different ambient conditions (e.g., the first pass was always conducted during the day whereas the second pass was always at night). Thus, it was reasoned that the effect of ambient conditions on energy requirements should be analyzed in terms of energy per unit mass water removed for each drying pass.

Figure 4 shows $\mathrm{E}_{\text {thermal }}, \mathrm{MC}_{\mathrm{i}}$, and average ambient $\mathrm{T}$ and $\mathrm{RH}$ for the preheating step and for each drying run of the drying tests performed in 2011 and 2012. Figure 4 indicates that the energy required to remove water from rice was considerably less when using the pre-heating bin than when using the dryer. It is reasoned that the low airflow rate used in preheating, in combination with the generally high $\mathrm{MC}$ of the incoming rice led to near saturation of the preheating air and thus a maximum water-uptake capacity. The results shown in figure 4 suggest that the pre-heating step was very energy efficient operation that may improve the overall energy efficiency of the drying process. Additionally, for tests 1, 4, and 5 of 2011, which were conducted in two passes, it was observed that $\mathrm{E}_{\text {thermal }}$ of the second pass was greater than that of the first pass. A possible explanation could be that more energy is required to remove a unit mass of water from rice with lesser MCs (Aviara et al., 2004; Mulet et al., 1999; Tsami et al., 1990; Zuritz and Singh,
1985). It might also be that the second passes were conducted at night when ambient air Ts were less (fig. 4). As average ambient $T$ decreases, more energy is required to heat the air to the drying $\mathrm{T}$. It is also observed in figure 4 that test 3 of 2011, which comprised a single pass and had the greatest average ambient $T$, required the least $E_{\text {thermal }}$. The relevance of ambient $\mathrm{T}$ can also be observed in test 5 of 2011; it is observed that the energy requirements for the first pass are similar to those of the second pass probably because the ambient $\mathrm{T}$ of the first pass $\left(20^{\circ} \mathrm{C}\right)$ was similar to that of the second pass $\left(17^{\circ} \mathrm{C}\right)$ for this test. Otten et al. (1980) reported that $E_{\text {thermal }}$ to dry corn in a commercial, cross-flow dryer increased from 4,970 to $11,960 \mathrm{~kJ} / \mathrm{kg}$ water removed when ambient $\mathrm{T}$ correspondingly decreased from $16.7^{\circ} \mathrm{C}$ to $-4.4^{\circ} \mathrm{C}$.

Based on the results shown in figure 4 , a potential approach to save energy could be to dry rice from $\mathrm{MC}_{\mathrm{i}}$ to $\sim 15 \%$ using the cross-flow dryer and to remove the remaining moisture using low-T or natural air in-bin drying as suggested by Morey et al. (1976) for corn. Considerable energy savings could be achieved using this approach because the sensible heat that remains inside rice kernels after high-T drying could be used to help reduce the $\mathrm{MC}$ to the desired $\mathrm{MC}_{\mathrm{f}}$; Morey et al. (1976), who used computer simulation to predict energy requirements, reported that $60 \%$ more energy is required to dry corn from $32 \%$ to $15 \%$ in a high-T dryer than to dry corn from $32 \%$ to $24 \%$ in a high-T dryer and complete drying to $15 \%$ in-bin using ambient air.

Figure 5 shows the effect of ambient $\mathrm{T}$ on $\mathrm{E}_{\text {thermal }}$ for the drying tests performed in 2011 and 2012. Thermal energy requirements were inversely and linearly correlated $\left(\mathrm{R}^{2}=0.62\right)$ to average ambient T. Otten et al. (1980) showed that the greater $\mathrm{E}_{\text {thermal }}$ values observed when drying at lesser ambient Ts could be partly due to greater heat losses to the surroundings. Bakker-Arkema et al. (1978) explained that the magnitude of the heat losses by radiation and convection to the atmosphere, through cracks in hot-air ducts and due to inefficiencies in fuel combustion depends on the type of dryer. It is reasonable that the heat losses described by Bakker-Arkema et al. (1978) increase as ambient $\mathrm{T}$ decreases. It is then possible that the figure 5 trend indicating that as ambient $\mathrm{T}$ decreases, $\mathrm{E}_{\text {thermal }}$ increases, is not only due to an increase in the energy required to heat the ambient air to the drying $\mathrm{T}$, but also to an increase in heat losses throughout the dryer. The simple linear regression model suggests that $38 \%$ of the variability in $\mathrm{E}_{\text {thermal }}$ was not explained by ambient $\mathrm{T}$. It is possible that other factors, such as rice $\mathrm{MC}$ and drying air conditions were responsible for some of the variability in $\mathrm{E}_{\text {thermal }}$.

Figure 6 shows the effect of ambient T, RH, and equilibrium $\mathrm{MC}$ on the thermal energy efficiency (eq. 3) per drying run. Equilibrium $\mathrm{MC}$ was calculated from the ambient air $\mathrm{T}$ and $\mathrm{RH}$ using the Chung-Pfost equation (Chung and Pfost, 1967; Pfost et al., 1976) and the coefficients reported by Ondier et al. (2011) for long-grain rice cultivars. Energy efficiency might be a more appropriate indicator than $\mathrm{E}_{\text {thermal }}$ of the effects of ambient conditions because the effects of $\mathrm{MC}_{\mathrm{i}}, \mathrm{MC}_{\mathrm{f}}$, and kernel $\mathrm{T}$ are accounted for in the calculation of $\mathrm{E}_{\text {theo }}$. Energy 

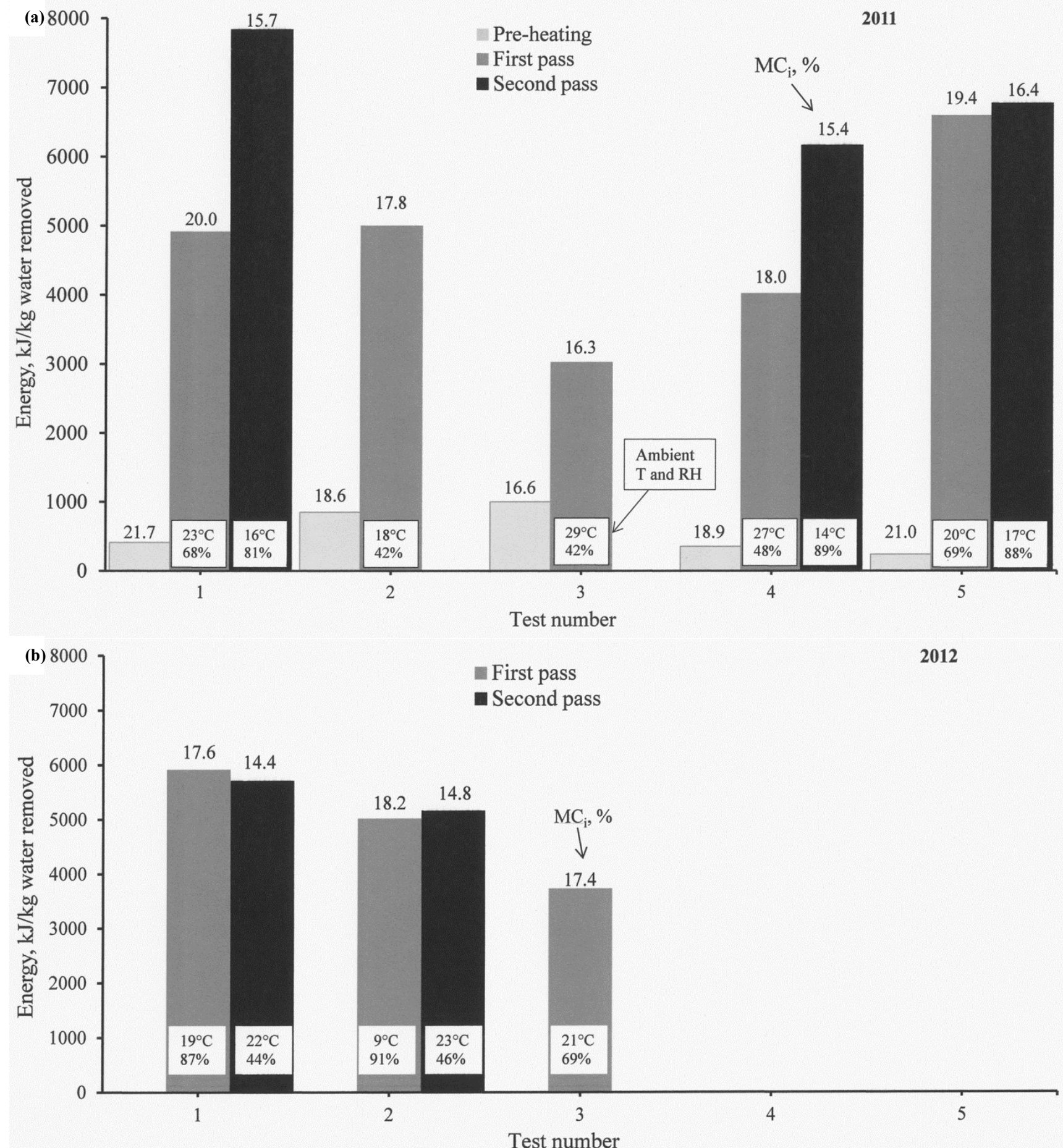

Figure 4. Thermal energy $\left(E_{\text {thermal }}\right)$ per drying run, to dry rice from the indicated initial moisture contents $\left(\mathrm{MC}_{\mathrm{i}} \mathrm{s}\right)$ for the five tests conducted during 2011 (a) and for the three tests conducted in 2012 (b), each with the indicated ambient temperatures (Ts) and relative humidities (RHs). Final moisture contents of the first pass were taken as the inlet $\mathrm{MC}_{\mathrm{i}} \mathrm{s}$ of the second pass. Final moisture contents of the second pass were $\sim 13 \%$. Note: The energy requirements for pre-heating rice in 2012 was not available as separate values but rather is included in the first pass values.

efficiency was strongly and linearly correlated $\left(\mathrm{R}^{2}=0.74\right)$ to average ambient $\mathrm{T}$, as it also was to $\mathrm{RH}\left(\mathrm{R}^{2}=0.41\right)$. Because energy efficiency increased as average ambient $\mathrm{T}$ increased, it is reasonable to suggest that as $\mathrm{RH}$ decreased, as is often associated with increasing ambient $\mathrm{T}$, energy efficiency increased. Equilibrium $\mathrm{MC}$ accounts for both $\mathrm{T}$ and $\mathrm{RH}$ associated with the drying air and reflect the drying potential of the drying air, which increases as $\mathrm{T}$ increases and RH decreases. Energy efficiency increased linearly as the rice equilibrium $\mathrm{MC}$ decreased. 


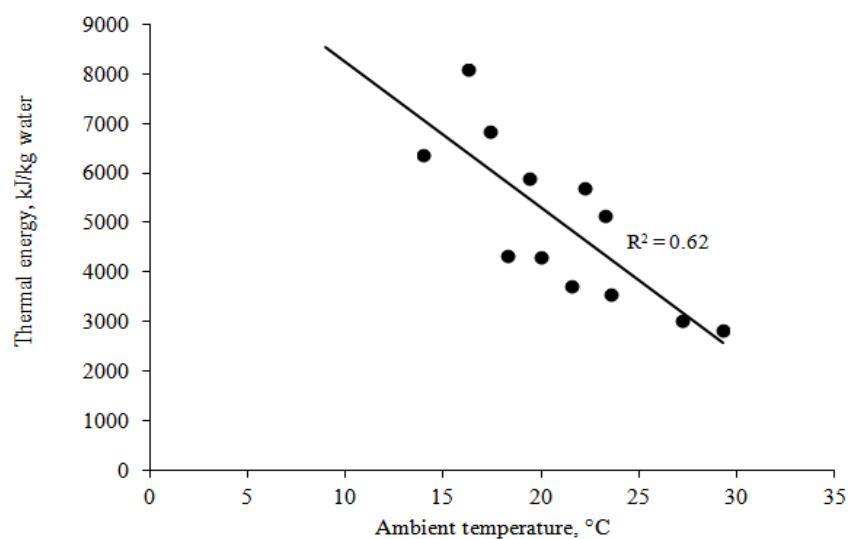

Figure 5. Thermal energy requirements $\left(E_{\text {thermal }}\right)$ per rice drying run, as a function of average ambient temperature for the energy tests performed in 2011 and 2012.
There was no correlation between drying air $\mathrm{T}$ and $\mathrm{E}_{\text {thermal. }}$. It is noted that drying air $\mathrm{T}$, which is expected to be a relevant factor affecting $\mathrm{E}_{\text {thermal }}$, ranged narrowly from $\sim 45$ to $55^{\circ} \mathrm{C}$ (table 1) during the tests; this may have caused the effect of drying air $\mathrm{T}$ on $\mathrm{E}_{\text {thermal }}$ to be lessened. The considerable variation in average ambient $\mathrm{T}$ observed among runs $\left(14^{\circ} \mathrm{C}\right.$ to $\left.29^{\circ} \mathrm{C}\right)$ was considered an additional drawback when assessing the effect of drying air $\mathrm{T}$.

\section{Prediction of Energy Use ANd EFficiency \\ Energy Use}

Even though there was no correlation between drying air $\mathrm{T}$ and $\mathrm{E}_{\text {thermal }}$, drying air $\mathrm{T}$ was included in the model predicting $\mathrm{E}_{\text {thermal }}$ in a term that quantified the difference between drying air $\mathrm{T}$ and ambient air $\mathrm{T}\left(\mathrm{T}_{\mathrm{da}}-\mathrm{T}_{\mathrm{a}}\right)$, which determines the amount of energy required to heat ambient air to the drying T. Additionally, the amount of water removed, expressed per unit of rice dry matter $\left(\mathrm{m}_{\mathrm{w}} / \mathrm{dm}\right)$,

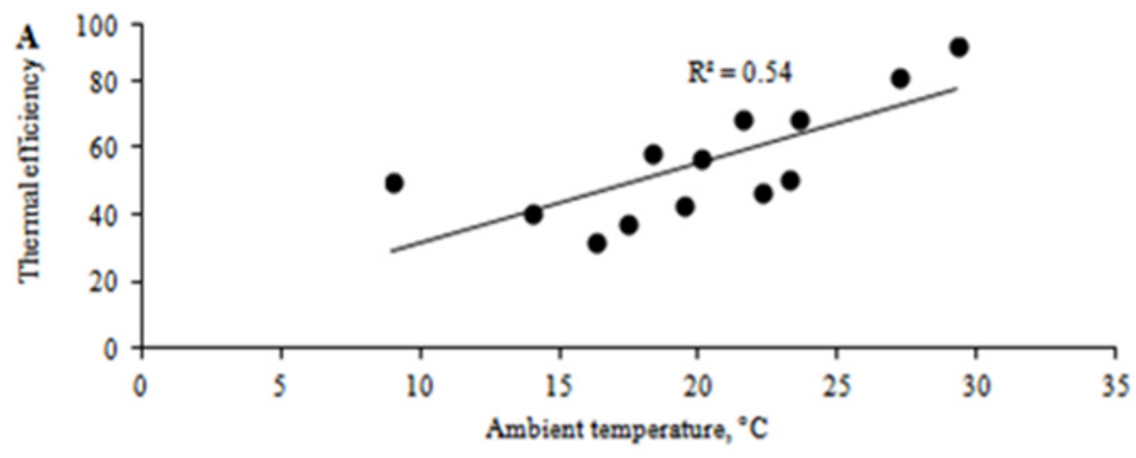

B
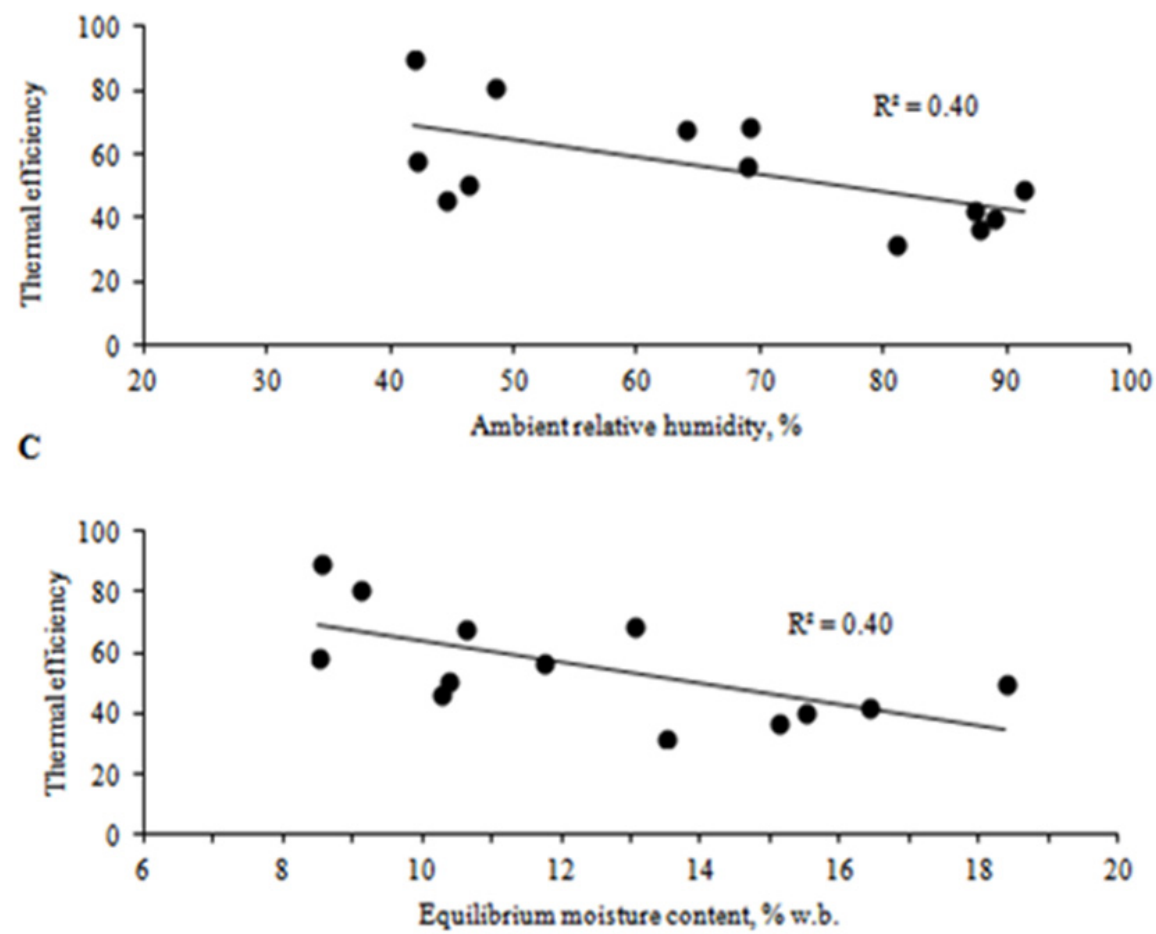

Figure 6. Thermal energy efficiency per drying run, calculated as the ratio of theoretical energy requirements $\left(E_{\text {theo }}\right)$ divided by the measured thermal energy $\left(E_{\text {thermal }}\right.$ ), of the on-farm dryer as a function of average ambient temperature (a), average ambient relative humidity (b) and rough rice equilibrium moisture content associated with the ambient air temperature and relative humidity predicted by the Chung-Pfost equation (c). 
was reasoned to affect energy use and was included as an independent variable of the model. Multiple linear regression analysis was used to obtain the coefficients $\left(b_{0}\right.$, $\mathrm{b}_{1}$, and $\mathrm{b}_{2}$ ) of equation 5 .

$$
\begin{gathered}
\mathrm{E}_{\text {thermal }}=\mathrm{b}_{1}\left(\mathrm{~T}_{\mathrm{da}}-\mathrm{T}_{\mathrm{a}}\right)+\mathrm{b}_{2}\left(\frac{\mathrm{m}_{\mathrm{w}}}{\mathrm{dm}}\right)+\mathrm{b}_{0} \\
\mathrm{R}^{2}=0.80 \quad \text { RMSE }=815
\end{gathered}
$$

$\mathrm{b}_{0}=2,048$

$\mathrm{b}_{1}=214$

$\mathrm{b}_{2}=-54,792$

$\mathrm{m}_{\mathrm{w}}=$ the mass of water removed in a drying run $(\mathrm{kg})$

$\mathrm{dm}=$ the mass of rice dry matter in a drying run $(\mathrm{kg})$

Dry matter was calculated using equation 6 .

$$
\mathrm{dm}=\left(1-\frac{\mathrm{MC}_{\mathrm{i}}}{100}\right) \mathrm{m}_{r}
$$

$\mathrm{MC}_{\mathrm{i}}=$ the average moisture content of the rice entering a drying run (\%, w.b.)

$\mathrm{m}_{\mathrm{r}} \quad=$ the mass of incoming rice dried in a drying run

The model suggests that $\mathrm{E}_{\text {thermal }}$ increased linearly as $T_{d a}-T_{a}$ increased. This is reasonable given that the greater the difference between drying air $\mathrm{T}$ and ambient air $\mathrm{T}$, the greater the amount of energy required to heat the air. The model also indicated that as $\mathrm{m}_{\mathrm{w}} / \mathrm{dm}$ increased, $\mathrm{E}_{\text {thermal }}$ decreased. In general, the drying operation consisted of two passes; the first pass, in which rice was dried from harvest $\mathrm{MC}(\sim 21 \%$ to $18 \%)$ to $\sim 15 \%$, and the second pass, in which rice was dried from $\sim 15 \%$ to $\sim 13 \%$. Thus, on average $\mathrm{mw} / \mathrm{dm}$ was greater

(a)

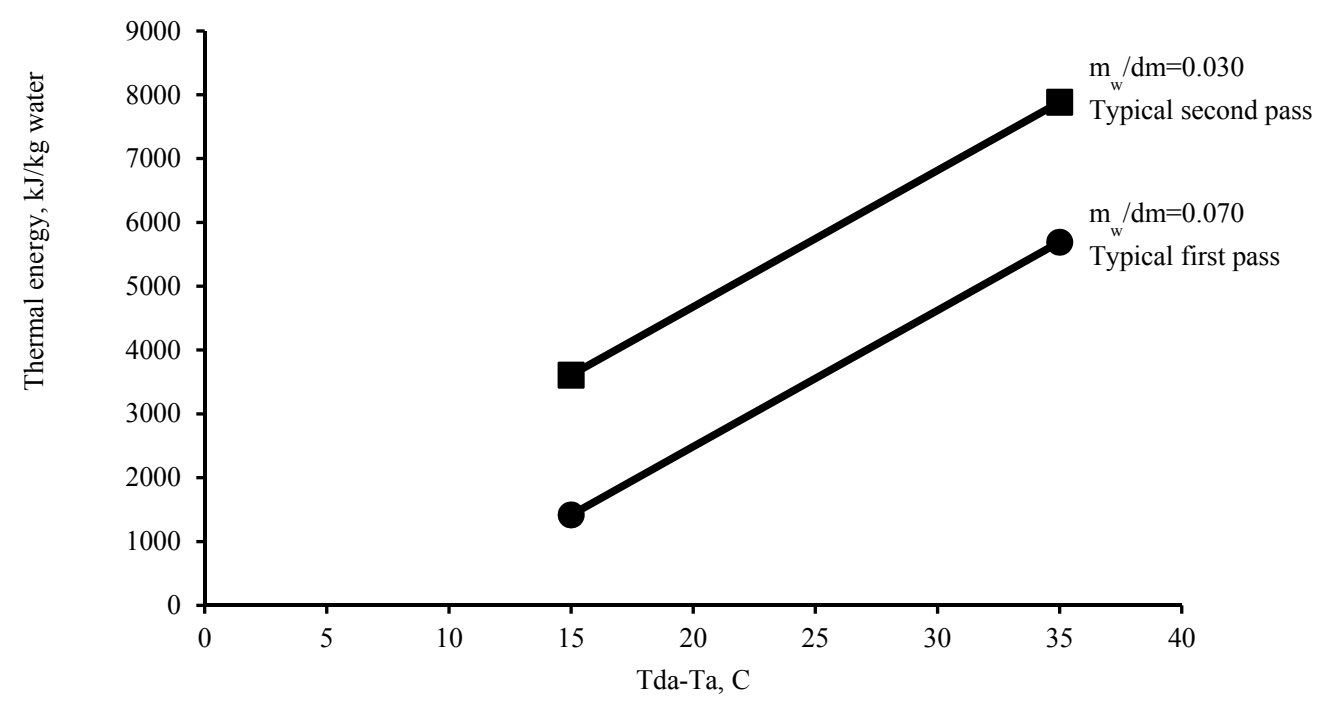

(b)

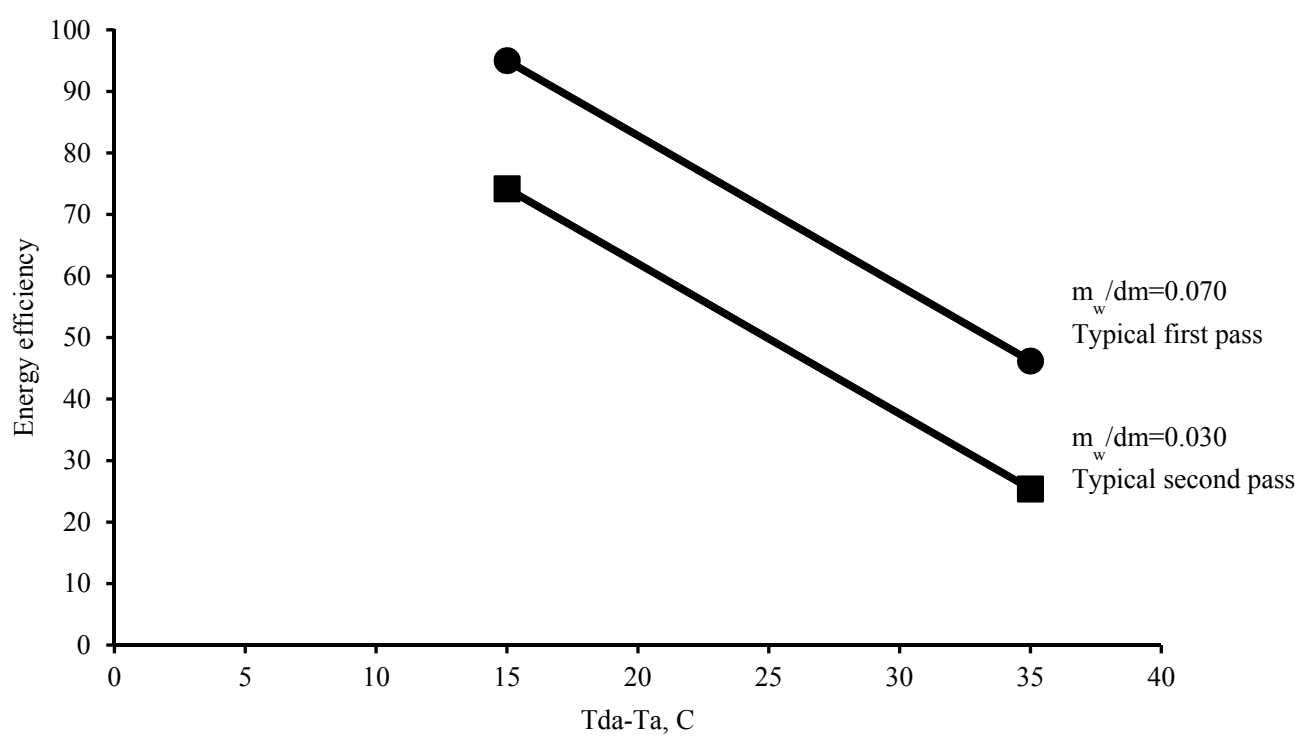

Figure 7. Family of curves predicting thermal energy use (a) and thermal energy efficiency (B) as a function of the difference between drying air temperature and ambient temperature $\left(T_{d a}-T_{a}\right)$ at the indicated levels of water removed per mass dry matter $\left(m_{w} / d m\right)$ for drying tests conducted in 2011 and 2012. Drying air temperatures ranged from $45^{\circ} \mathrm{C}$ to $55^{\circ} \mathrm{C}$ and ambient air temperatures ranged from $15^{\circ} \mathrm{C}$ to $30^{\circ} \mathrm{C}$. 
during the first pass $(\sim 0.070)$ than during the second pass $(\sim 0.030)$. Because it is increasingly difficult to remove water as $\mathrm{MC}$ decreases it is then reasonable that $\mathrm{E}_{\text {thermal }}$ increased as $\mathrm{m}_{\mathrm{w}} / \mathrm{dm}$ decreased (fig. $7 \mathrm{~A}$ ).

\section{Thermal Energy Efficiency}

In an effort to model thermal efficiency, multiple linear regression analysis was used to obtain the coefficients $\left(b_{0}\right.$, $\mathrm{b}_{1}$, and $\mathrm{b}_{2}$ ) of equation 7 .

$$
\begin{gathered}
\eta_{\text {th }}=b_{1}\left(T_{d a}-T_{a}\right)+b_{2}\left(\frac{m_{w}}{d m}\right)+b_{0} \\
R^{2}=0.72 \quad \text { RMSE }=11
\end{gathered}
$$

$\eta_{\text {th }}=$ thermal energy efficiency of a drying run

$\mathrm{b}_{0}=95.2$

$\mathrm{b}_{1}=-2.4$

$\mathrm{b}_{2}=520$

The model shows that the greater the difference, $T_{d a}-T_{a}$, the lesser the thermal efficiency. An explanation for this would be that as ambient $\mathrm{T}$ decreases, which leads to an increase in $\mathrm{E}_{\text {thermal }}$ (fig. 5), $\mathrm{E}_{\text {thermal }}$ becomes greater relative to $\mathrm{E}_{\text {theo }}$. In addition, as $\mathrm{m}_{\mathrm{w}} / \mathrm{dm}$ increased, energy efficiency increased (fig. 7B). It was reasoned that because $\mathrm{E}_{\text {thermal }}$ increased as $\mathrm{m}_{\mathrm{w}} / \mathrm{dm}$ decreased (fig. 7A), thermal efficiency decreased as $\mathrm{m}_{\mathrm{w}} / \mathrm{dm}$ decreased.

\section{Drying Cost}

To perform cost calculations, the price of liquid propane was taken as $\$ 529 / \mathrm{m}^{3}$ (\$2.0/gal), which was the price paid for propane in 2011. The heat of combustion for propane gas was taken as $\sim 93,743 \mathrm{~kJ} / \mathrm{m}^{3}\left(2,516 \mathrm{Btu} / \mathrm{ft}^{3}\right)$. The density of liquid propane was taken as $500 \mathrm{~kg} / \mathrm{m}^{3}$ and the density of propane gas was taken as $1.9 \mathrm{~kg} / \mathrm{m}^{3}$ (at $15^{\circ} \mathrm{C}$ and $101.3 \mathrm{kPa}$ ). Thus, $263 \mathrm{~m}^{3}$ of gas are obtained from $1 \mathrm{~m}^{3}$ of liquid propane. Equation 8 was developed using equation 7 and the price of propane in $\left(2.1^{-3} \notin / \mathrm{kJ}\right)$.

$$
\begin{aligned}
& \text { Cost }= \\
& 2.1^{-3} \mathrm{E}_{\text {thermal }}=4.5^{-1}\left(\mathrm{~T}_{\mathrm{da}}-\mathrm{T}_{\mathrm{a}}\right)-115\left(\frac{\mathrm{m}_{\mathrm{w}}}{\mathrm{dm}}\right)+4.3
\end{aligned}
$$

Cost is the cost to dry rice in $\varnothing / \mathrm{kg}$ water removed.

The family of curves for drying cost as a function of $\mathrm{T}_{\mathrm{da}}-\mathrm{T}_{\mathrm{a}}$ for two levels of $\mathrm{m}_{\mathrm{w}} / \mathrm{dm}$ is shown in figure 8. As expected, the trends in Cost are similar to those of $\mathrm{E}_{\text {thermal }}$, given that the greater the energy use the greater the amount of propane used and thus the greater the cost.

\section{CONCLUSIONS}

Thermal energy use $\left(\mathrm{E}_{\text {thermal }}\right)$ to dry rice in the on-farm, cross-flow dryer ranged from 2,840 to $5,840 \mathrm{~kJ} / \mathrm{kg}$ water removed for the eight tests conducted during the 2011 and 2012 harvest seasons. Thermal energy efficiency, which was calculated as the ratio of the theoretical energy requirements $\left(E_{\text {theo }}\right.$ ) to $E_{\text {thermal }}$, ranged from $44 \%$ to $90 \%$. The cost to dry rice from the initial moisture contents, ranging from 16.6 to 21.7 to $\sim 13 \%$ ranged from 7.7 to $12.0 \AA / \mathrm{kg}$ water removed. There was a strong correlation between $\mathrm{E}_{\text {thermal }}$ and ambient air temperature. It was also found that $\mathrm{E}_{\text {thermal }}$ was linearly correlated to the difference between the drying air temperature and ambient air temperature, which is an indicator of the energy required to heat the air to the drying temperature. $\mathrm{E}_{\text {thermal }}$ was also inversely correlated to the amount of water removed, expressed per unit mass of dry matter. Equations were developed to predict $\mathrm{E}_{\text {thermal }}$, energy efficiency and drying cost as a function of these variables.

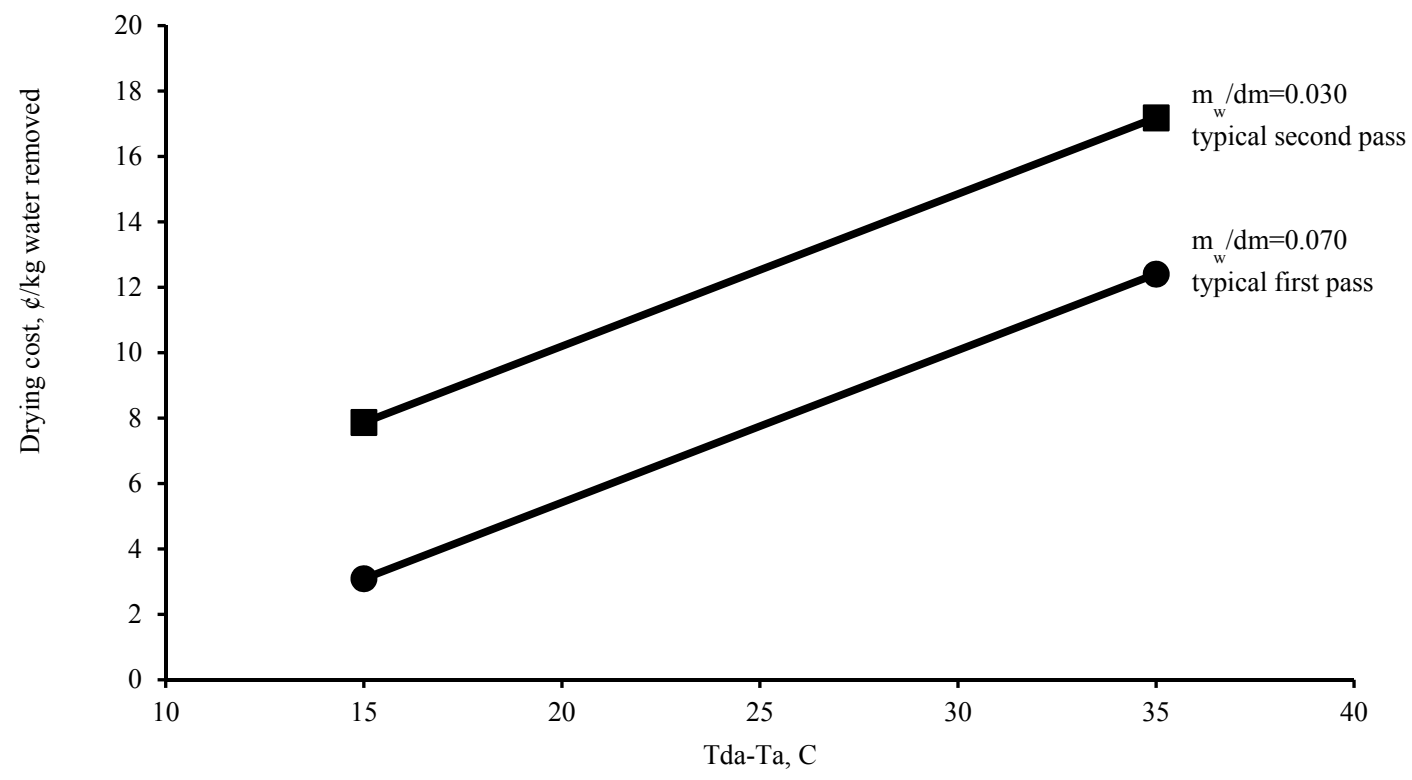

Figure 8. Family of curves predicting drying cost as a function of the difference between drying air temperature and ambient temperature $\left(\mathrm{T}_{\mathrm{da}}{ }^{-}\right.$ $\left.T_{a}\right)$ at the indicated levels of water removed per mass dry matter $\left(m_{w} / \mathbf{d m}\right)$ for drying tests conducted in 2011 and 2012. Drying air temperatures ranged from $45^{\circ} \mathrm{C}$ to $55^{\circ} \mathrm{C}$ and ambient air temperatures ranged from $15^{\circ} \mathrm{C}$ to $30^{\circ} \mathrm{C}$. 


\section{REFERENCES}

Aviara, N. A., Ajibola, O. O., \& Oni, S. A. (2004). Sorption equilibrium and thermodynamic characteristics of soya bean. Biosyst. Eng., 87(2), 179-190. doi:http://dx.doi.org/10.1016/j.biosystemseng.2003.11.006

Bakker-Arkema, F. W., \& Fontana, C. (1983). Comparison of rice drying systems. ASAE Paper No. 83-3532. St. Joseph, Mich.: ASAE.

Bakker-Arkema, F. W., Lerew, L. E., Brook, R. C., \& Brooker, D. B. (1978). Energy and capacity performance evaluation of grain dryers. ASAE Paper No. 78-3523, St. Joseph, Mich.: ASAE.

Billiris, M. A., Siebenmorgen, T. J., \& Mauromoustakos, A. (2011). Estimating the theoretical energy required to dry rice. $J$. of Food Eng., 107(2), 253-261. doi:http://dx.doi.org/10.1016/j.jfoodeng.2011.06.015

Brinker, J. L., \& Anderley, N. (2012). Energy efficiency data comparison of ten Wisconsin grain dryer installations. ASABE Paper No. 12-1337410, St. Joseph, Mich.: ASABE.

Chung, D. S., \& Pfost, H. B. (1967). Adsorption and desorption of water vapor by cereal grains and their products. Part 2. : Development of the general isotherm equation. Trans. ASAE, 10(4), 549-555. doi:http://dx.doi.org/10.13031/2013.39726

Economic Research Service. (2004). Characteristics and production costs of U.S. rice farms. Washington, D.C.: USDA.

Fluck, R. C., \& Baird, C. D. (1980). Energy requirements for agricultural inputs. In Agricultural Energetics (p. 87). Westport, Conn.: AVI Publishing Company, Inc.

Hellevang, K. J., \& Reff, T. (1987). Calculating grain drying cost. Fargo, N.D.: North Dakota State University of Agriculture and Applied Science, NDSU Extension Service and U.S. Department of Agriculture.

Howell, T. A., \& Cogburn, R. R. (2004). Rough-rice storage. In Rice Chemistry and Technology (Vol. Third, p. 269). St. Paul, Minn.: American Association of Cereal Chemists, Inc.

Kasmaprapruet, S. W. (2009). Life cycle assessment of milled rice production: Case study in thailand. European J. of Sci. Res., 30(2), 195-203.

Kudra, T. (2004). Energy aspects in drying. Drying Tech., 22(5), 917-932. doi:http://dx.doi.org/10.1081/DRT-120038572

Maier, D. E., \& Bakker-Arkema, F. W. (2002). Grain drying systems. In Facility Design Conference of Grain Elevator \& Processing Society. Minneapolis, Minn.: GEAPS.

Morey, R. V., Cloud, H. A., \& Lueschen, W. E. (1976). Practices for efficient utilization of energy for drying corn. Trans. ASAE, 19(1), 151. doi:http://dx.doi.org/10.13031/2013.35985

Mujumdar, A. S. (1995). Handbook of Industrial Drying (Vol. 2). New York, N.Y.: Dekker.

Mulet, A., García-Reverter, J., Sanjuán, R., \& Bon, J. (1999). Sorption isosteric heat determination by thermal analysis and sorption isotherms. J. of Food Sci., 64(1), 64-68. doi:http://dx.doi.org/10.1111/j.1365-2621.1999.tb09862.x

Neil, P. (2003). Combined Heating, Cooling and Power Handbook: Technologies and Applications. Lilburn, Ga.: The Fairmont Press.

Ondier, G. O., Siebenmorgen, T. J., Bautista, R. C., \& Mauromoustakos, A. (2011). Equilibrium moisture contents of pureline, hybrid, and parboiled rice. Trans. ASABE, 54(3), 10071013. doi:http://dx.doi.org/10.13031/2013.37085

Otten, L. R. (1980). A study of a commercial cross-flow dryer. Canadian Agric. Eng., 22(2), 163-170.

Pfost, H. B., Maurer, S. G., Chung, D. S., \& Milliken, G. A. (1976). Summarizing and reporting equilibrium moisture data for grains. ASAE Paper No. 76-3520, St. Joseph, Mich.: ASAE.

RiceTec Grain Quality Profiler. (2013). Retrieved from RiceTec: http://www.ricetec.com/Default.aspx?SiteSearchID=2281\&ID=/ search_results.htm

Sarker, N. N., Kunze, O. R., \& Strouboulis, T. (1996). Transient moisture gradients in rough rice mapped with finite element model and related to fissures after heated air drying. Trans. ASAE, 39(2), 625-631. doi:http://dx.doi.org/10.13031/2013.27544

Siebenmorgen, T. J., \& Meullenet, J.-F. (2004). Impact of drying, storage, and milling on rice quality and functionality. In E. T. Champagne (Ed.), Rice Chemistry and Technology (3rd ed., p. 301). St.Paul, Minn.: American Association of Cereal Chemists. doi:http://dx.doi.org/10.1094/1891127349.012

Tsami, E., Maroulis, Z. B., Marinos-Kouris, D., \& Saravacos, G. D. (1990). Heat of sorption of water in dried fruits. Intl. J. of Food Sci. and Tech., 25, 350. doi:http://dx.doi.org/10.1111/j.13652621.1990.tb01092.x

USDA. (2013). National Agricultural Statistics Service of the United States Department of Agriculture. http://quickstats.nass.usda.gov/results/729FBB55-95EE-3CAE8779-F99D12FFE356?pivot=short_desc. Accessed in March 2013.

USDA. (2011). Cropproductionreports. Retrieved from http://www.nass.usda.gov/Charts_and_Maps/graphics/riceacm.pdf

Verma, L. R. (1994). New methods for on-the-farm rice drying: solar and biomass. In E. M. Wayne, \& J. I. Wadsworth (Eds.), Rice Science and Techology. New York, N.Y.: Marcel Dekker, Inc.

Yang, W., Jia, C. C., Siebenmorgen, T. J., Pan, Z., \& Cnossen, A. G. (2003). Relationship of kernel moisture content gradients and glass transition temperatures to head rice yield. Biosyst. Eng., 85(4), 467-476. doi:http://dx.doi.org/10.1016/S15375110(03)00091-6

Zuritz, C. A., \& Singh, R. P. (1985). An equation to compute the heat of evaporation of water for rough rice during drying. Drying Tech., 3(3), 421-435. doi:http://dx.doi.org/10.1080/07373938508916279 